\title{
Harvesting and Storage Conditions for Pineapples of the Red Spanish Variety ${ }^{1}$
}

\author{
H. L. Cancel ${ }^{2}$
}

\section{INTRODUCTION}

Pineapple (Anana comosus $L$.) is the most important economic fruit crop of Puerto Rico. As previously reported by Ramírez et al. (12) the Puerto Rican pineapple industry "is a twofold industry consisting of: 1, Fresh fruit for both local and the United States markets, and 2, canning in various forms for both local and export trade". The fresh fruit brings the highest return for the grower. There is a good although limited market for this fresh produce on the U.S.A. mainland, and about 35 percent of the local production is currently shipped to stateside ports in refrigerated vans. During the year 1971, 24,839 tons were exported at an average price of \$68.06 per ton (2).

To prevent deterioration of the fruit in transit, pineapples used for exportation are harvested at a stage of maturity called "shipping green." They are wrapped in cellophane paper, packed in cartons, and shipped in refrigerated vans. According to the exporters these pincapples continue to ripen during shipment thus improving the quality stage as compared to that at time of harvest.

Dull et al. (4) in their studies concluded that the pineapple fruit has a nonclimacteric pattern. Biale (3) made a statement for nonclimateric fruit that ". . . for best quality they must be left on the tree until the desirable composition is reached." According to this information, pincapple fruit used for export and storage should be harvested at a stage of maturity in which the edible quality characteristics are present as nearly like those of ripe fruit as possible.

Several publications recommend that the pineapple should be harvested at a stage of maturity in which the quality is acceptable at the consumer level. Akamine (1), working with the Smooth Cayenne variety, concluded that mature green fruit should not be used for shipping. Kelly (7) showed that the pineapple fruit in the green stage does not store reserve material which later may be converted into sugar.

In Puerto Rico, the Red Spanish is the most extensively grown variety of pincapple. Morell et al. (10) reported that Red Spanish had very good qualities for shipment as fresh fruit and a very good acceptance in the U.S.

1 Manuscript submitted to Editorial Board August 9, 1973.

2 Assistant Food Technologist, Food Technology Laboratory, Agricultural Lxperiment Station, Mayagüez Campus, University of Puerto Rico, Río Piedras, P.R. 
market. However, most of the available literature on transportation and storage is on the Smooth Cayenne variety. Very little research has been done with Red Spanish in regard to transportation and storage.

Henricksen (6) studied the maturity levels and the chemical composition of the Red Spanish variety. He found that the ratio of reducing sugars to nonreducing sugars varied according to the maturation of the fruit, being about equal in the half-developed fruit, from 1 to 2.5 in the fully developed fruit, and 1 to 3 or 1 to 4 in the plant-ripened fruit.

Many attempts have been made to relate an external factor of the fruit with its maturity, but no conclusive evidence has been proved useful so far. Py (11) proposed a classification based on the apparent ripeness by observing the changes in the color of the peel. Three different apparent ripeness indices were presented: 1 , Initial or turning $\left(M_{1}\right)$, when an orangeyellow coloration appears at the base of the fruit; 2 , half-ripe $\left(\mathrm{M}_{2}\right)$, when the color extends to the middle of the fruit; and 3, ripe $\left(\mathrm{M}_{3}\right)$, when the colored area extends beyond half of the fruit.

The most serious problem during transit is the decay caused by fungi, mainly Thielaviopsis paradoxa. According to Liu and Rodriguez (9) isolated colonies of this fungus had an optimum growth temperature between $75.2^{\circ} \mathrm{F}\left(24^{\circ} \mathrm{C}\right)$ and $82.4^{\circ} \mathrm{F}\left(28^{\circ} \mathrm{C}\right)$, but showed no growth at temperatures below $53.6^{\circ} \mathrm{F}\left(12^{\circ} \mathrm{C}\right)$. Py (11) states that if the fruits are shipped at temperatures between $44.6^{\circ} \mathrm{F}\left(7^{\circ} \mathrm{C}\right)$ and $46.4^{\circ} \mathrm{F}\left(8^{\circ} \mathrm{C}\right)$ Thielaviopsis paradoxa practically does not develop.

Great losses occur occasionally due to rotting of the fruit, probably due to excessively high temperatures and lack of proper air circulation during transportation. Little research has been done in Puerto Rico on the control of conditions inside refrigerated vans.

This research was undertaken to determine the possibility of harvesting Red Spanish pineapple fruits beyond the shipping green stage and their keeping qualities under controlled shipping storage conditions of temperature and relative humidity.

\section{MATERIALS AND METHODS}

Pineapples of the Red Spanish variety were harvested at the Puerto Rico Land Authority plantations in the Barceloneta and Manati regions of Puerto Rico. These were sorted as to size, ripeness and damage. The apparent ripeness of the fruit was classified into four different stages: 1 , "Shipping green," the stage of ripeness at which the local growers export the fruit; 2, "one-fourth-ripe," indicated by a yellow-orange coloration appearing at the base of the fruit; 3 , "half-ripe," when the yellow zone had extended from the base to the middle of the fruit; and 4, "fully ripe," when the yellow zone had extended beyond the middle of the fruit. In 
most of the samples harvested, the yellow zones were not clearly demarked, and the selection was made on the basis of averaging the area which had turned yellow.

During harvest, the samples were treated as if for commercial purposes, and a fungicide (Dowicide $\mathrm{A})^{3}$ was applied at the stem-end immediately after harvest.

The fruit samples were brought to the Food Technology Laboratory and again sorted for size and damage prior to packing. Only size No. $12^{4}$ fruits were used in these experiments. After sorting and packing in cartons with venting holes, they were placed under controlled conditions in Forma Scientific environmental rooms, the interior dimensions of which were 5 feet 2 inches wide, 6 feet 6 inches deep, and 7 feet 1 inch high, in which the temperature and relative humidity were controlled within the pre-set limits. These rooms were equipped with a continuous internal air flow that varied from $325 \mathrm{cfm}$ in the area of maximum air flow to $51 \mathrm{cfm}$ in the area of minimum ventilation.

To simulate storage conditions during shipping, the samples were subjected to temperatures of $40^{\circ} \mathrm{F}$. $\left(4.4^{\circ} \mathrm{C}\right), 45^{\circ} \mathrm{F}\left(7.2^{\circ} \mathrm{C}\right)$, and $50^{\circ} \mathrm{F}\left(10.0^{\circ}\right.$ C), and to relative humidities of 70,80 , and 90 percent for 7 days. After the first storage period the samples were held at $60^{\circ} \mathrm{F}\left(15.6^{\circ} \mathrm{C}\right)$ and $75-$ percent relative humidity until the termination of the experiment. The latter figures are the average conditions under which Puerto Rican supermarkets hold this type of produce.

While in storage, the samples were inspected periodically for decay and other detrimental factors which impair quality. Samples also were taken out for sensory evaluation and chemical analyses.

Different approaches were made in selecting a procedure for sensory evaluation. Pulp samples were presented to a taste panel in tidbits (chunks), crushed, and in lengthwise wedges or boat form. Two fruits of each stage of ripeness were used for preparing the analytical samples. Each fruit was peeled and cored in a Ginaca-type machine. The pulp cylinders were cut in half, one half from each fruit was used to prepare a sample for chemical analyses and the other two halves for the corresponding samples for an organoleptic evaluation.

3 Trade names are used in this publication solely for the purpose of providing specific information. Mention of trade names does not constitute a guarantee or warranty of the product or equipment by the Agricultural Experiment Station of the University of Puerto Rico or an endorsement over other product or equipment not mentioned.

- Puerto Rican pineapples are classified according to the number of fruits that fit in a $12 \times 12 \times 16.5$-inch carton. No. 12 thus stands for 12 fruits per carton. The diameter for this type of fruit varies from $4 \frac{3}{4}$ inches to $51 / 4$ inches and the average weight is 3 pounds 2 ounces (5). 
Chemical analyses were made from the juice of the macerated fruit pulp samples after they were passed through a cloth.

The analyses included reducing sugars, total sugars as invert, and soluble solids. Taste panel evaluations were rated using wedges of samples, and the rating scores were based on the 5-point Hedonic scale used in the Kramer and Ditman method (8) in which a +2 , and a -2 , or acceptable, and nonacceptable criteria are used.

Fresh pineapple fruit samples were evaluated to determine the most satisfactory procedure to correlate the sensory evaluation with the chemical analyses. The results of the evaluation were:

1. Crushed pulp-This method was rejected because the taste panelists were not accustomed to eating fresh pineapple in this form.

2. Tidbits-The results obtained by this method were very misleading. Although the samples were randomized, there were great differences between pieces of the same sample, which made, the rating very erratic. These differences are due to the maturity pattern of the pineapple fruit as the base of the fruit matures carlier than the top.

3. Lengthwise wedges-Lengthwise wedge samples were cut from a pulp cylinder. The panelists were instructed to taste at least both ends and the middle of the sample and then base the rating on the whole sample. This was the most acceptable method as it represented the different degrees of ripeness within a sample.

\section{RESULTS AND DISCUSSION}

The chemical analyses and sensory evaluation tests performed during the storage experiment are presented on table 1. The results show that fruit classified as "shipping green" rated lower in the sensory evaluation than the other stages of ripeness. The average percentages of total sugars and soluble solids expressed as degrees Brix were much lower in the "shipping green" samples than in any of the other three stages of apparent ripeness, but in the "one-fourth-ripe" they were higher than in the "shipping green" and very close to those in the "half-ripe" and "fully ripe" stages.

According to Henricksen's method of classification (6) and the data obtained from the analyses, the "shipping green" samples analyzed were undevcloped fruit. The average ratio of reducing to nonreducing sugars of the "shipping green" samples were 1 to 1.1, while the "one-fourth-ripe," with an average ratio of 1 to 2.9 can be classified as fully developed.

Data obtained from the statistical analyses of the chemical and sensory evaluation showed a significant difference at the 1-percent level between the "shipping green" samples and the other three stages of ripeness. The analysis also showed no significant differences in the subjective and ob- 
TABLE 1.-Chemical and sensory evaluation of Red Spanish pineapples during storage

\begin{tabular}{|c|c|c|c|c|c|c|c|}
\hline Sample & $\begin{array}{c}\text { Storage } \\
\text { time }\end{array}$ & Total sugars & $\begin{array}{c}\text { Reducing } \\
\text { sugars }\end{array}$ & $\begin{array}{c}\text { Non- } \\
\text { reducing } \\
\text { sugars }\end{array}$ & $\begin{array}{l}\text { Ratio of } \\
\text { reducing to } \\
\text { non- } \\
\text { reducing } \\
\text { sugars }\end{array}$ & Brix & $\begin{array}{c}\text { Sensory } \\
\text { cvaluation }\end{array}$ \\
\hline & Days & Percent & Percens & Percent & & Degrees & \\
\hline $\begin{array}{r}\text { Shipping } \\
\text { green }\end{array}$ & $\begin{array}{r}0 \\
7 \\
14 \\
21\end{array}$ & $\begin{array}{l}4.75 \\
8.12 \\
7.42 \\
7.08\end{array}$ & $\begin{array}{l}2.58 \\
3.59 \\
3.62 \\
3.10\end{array}$ & $\begin{array}{l}2.17 \\
4.53 \\
3.80 \\
3.98\end{array}$ & $\begin{array}{l}0.8 \\
1.3 \\
1.0 \\
1.3\end{array}$ & $\begin{array}{l}6.9 \\
9.4 \\
8.5 \\
8.5\end{array}$ & $\begin{array}{l}-1.6 \\
-1.3 \\
-1.5 \\
-1.5\end{array}$ \\
\hline Average & & 6.84 & 3.22 & 3.62 & 1.1 & 8.3 & -1.5 \\
\hline $\begin{array}{l}\text { One- } \\
\text { fourth- } \\
\text { ripe }\end{array}$ & $\begin{array}{r}0 \\
7 \\
14 \\
21\end{array}$ & $\begin{array}{l}10.07 \\
12.60 \\
10.90 \\
12.27\end{array}$ & $\begin{array}{l}2.57 \\
2.95 \\
3.05 \\
3.27\end{array}$ & $\begin{array}{l}7.50 \\
9.65 \\
7.85 \\
9.00\end{array}$ & $\begin{array}{l}2.9 \\
3.3 \\
2.6 \\
2.8\end{array}$ & $\begin{array}{l}13.6 \\
13.7 \\
12.2 \\
13.7\end{array}$ & $\begin{array}{l}0.05 \\
0.15 \\
0.00 \\
0.50\end{array}$ \\
\hline Average & & 11.46 & 2.96 & 8.50 & 2.9 & 13.3 & 0.18 \\
\hline Half-ripe & $\begin{array}{r}0 \\
7 \\
14 \\
21\end{array}$ & $\begin{array}{l}10.00 \\
13.08 \\
12.60 \\
11.19\end{array}$ & $\begin{array}{l}2.40 \\
3.20 \\
3.45 \\
2.87\end{array}$ & $\begin{array}{l}7.60 \\
9.88 \\
9.15 \\
8.32\end{array}$ & $\begin{array}{l}3.2 \\
3.1 \\
2.7 \\
2.9\end{array}$ & $\begin{array}{l}13.6 \\
14.0 \\
13.8 \\
12.7\end{array}$ & $\begin{array}{l}1.10 \\
0.95 \\
0.80 \\
*\end{array}$ \\
\hline Average & & 11.72 & 2.98 & 8.73 & 2.9 & 13.5 & 0.95 \\
\hline Fully ripe & $\begin{array}{r}0 \\
7 \\
14 \\
21\end{array}$ & $\begin{array}{l}11.50 \\
14.27 \\
13.26 \\
11.15\end{array}$ & $\begin{array}{l}2.71 \\
3.05 \\
3.74 \\
3.19\end{array}$ & $\begin{array}{r}8.79 \\
11.22 \\
9.52 \\
7.96\end{array}$ & $\begin{array}{l}3.2 \\
3.7 \\
2.5 \\
2.5\end{array}$ & $\begin{array}{l}15.4 \\
15.0 \\
14.2 \\
12.6\end{array}$ & $\begin{array}{l}0.94 \\
1.20 \\
0.70 \\
*\end{array}$ \\
\hline Average & & 12.55 & 3.17 & 9.37 & 3.0 & 14.3 & 0.95 \\
\hline
\end{tabular}

* Sample not evaluated due to decay.

TABLE 2.-Shelf-life, in days, of Red Spanish pineapple samples stored under controlled conditions ${ }^{1}$ of temperature and relative humidity

\begin{tabular}{lrrrrrr}
\hline \multirow{2}{*}{ Stage of ripeness } & \multicolumn{7}{c}{ Simulated shipping conditions of- } \\
\cline { 2 - 7 } & $\begin{array}{c}50^{\circ} \mathrm{F}-70 \% \\
\mathrm{RH}^{2}\end{array}$ & $\begin{array}{c}50^{\circ} \mathrm{F}-80 \% \\
\mathrm{RH}\end{array}$ & $\begin{array}{c}45^{\circ} \mathrm{F}-70 \% \\
\mathrm{RH}\end{array}$ & $\begin{array}{c}45^{\circ} \mathrm{F}-80 \% \\
\mathrm{RH}\end{array}$ & $\begin{array}{c}45^{\circ} \mathrm{F}-90 \% \\
\mathrm{RH}\end{array}$ & $\begin{array}{c}40^{\circ} \mathrm{F}-90 \% \\
\mathrm{RH}\end{array}$ \\
\hline Shipping green & $15-17$ & $15-17$ & $19-20$ & $19-20$ & $17-19$ & $17-19$ \\
One-fourth ripe & $14-17$ & $14-17$ & $15-17$ & $15-17$ & $15-17$ & $13-15$ \\
Half-ripe & $8-10$ & $8-10$ & $10-12$ & $10-12$ & $11-12$ & $11-12$ \\
Fully ripe & $8-10$ & $8-10$ & $10-12$ & $10-12$ & $11-12$ & $11-12$ \\
\hline
\end{tabular}

1 Controlled conditions were set for 7 days af ter which the conditions were changed to $60^{\circ} \mathrm{F}\left(15.6^{\circ} \mathrm{C}\right)$ and 75 -percent relative humidity in all storage tests.

$2 \mathrm{RH}=$ relative humidity. 
jective analysis between the "one-fourth-ripe" and the "half-ripe" and "fully ripe" fruits.

From the analytical data obtained it can be shown that the edible quality of the export fruit can be improved by harvesting at the "one-fourth-ripe" or riper stages.

According to Liu and Rodriguez (9) no growth of Thielaviopsis paradoxa occurred in vitro at temperatures below $54^{\circ} \mathrm{F}\left(12^{\circ} \mathrm{C}\right)$. In the experiperiments conducted at temperatures ranging from $40^{\circ} \mathrm{F}\left(4.4^{\circ} \mathrm{C}\right)$ up to $60^{\circ} \mathrm{F}\left(15.6^{\circ} \mathrm{C}\right)$ no evidence of this infection was found on the fruits. However, there were other fungal contaminations on the outside of the fruit, due mostly to Penicillium spp., although superficial and did not penetrate the pulp.

Table 2 shows results on shelf-life of pineapple when subjected to simulated transport and distribution conditions, as specified under Materials and Methods.

The results obtained from the analytical work and the data gathered during the storage tests suggest that the "half-ripe" and "fully ripe" samples may be grouped as one single stage of ripeness as they behaved in a very similar fashion.

Table 2 shows that the storage behavior of the fruit varied very slightly with the experimental temperatures and relative humidity settings used. Nevertheless, there were certain symptoms which deserved consideration. The "shipping green" samples suffered from chilling injury or part of the peel failed to turn orange after controlled storage at temperatures of $45^{\circ} \mathrm{F}$ $\left(7.2^{\circ} \mathrm{C}\right)$ and $40^{\circ} \mathrm{F}\left(4.4^{\circ} \mathrm{C}\right)$ for 7 days. The samples kept at $50^{\circ} \mathrm{F}\left(10.0^{\circ}\right.$ C) for the same period of time showed fewer chilling injury symptoms, but there was a greater superficial fungal growth, mostly Penicillium spp. In none of the storage tests did the "shipping green" samples attain the expected edible quality. Some samples kept at room temperature (around $75^{\circ} \mathrm{F}$ ) throughout the storage period were rated as "acceptable," but this can not be recommended as a commercial practice due to the possible spoilage of the load at such a high temperature.

The "one-fourth-ripe" fruit kept at $45^{\circ} \mathrm{F}\left(7.2^{\circ} \mathrm{C}\right)$ for 7 days under simulated transit conditions developed slight chilling injury. These samples developed a yellow color when subjected to supermarket conditions which also improved the appearance of the samples over the "shipping green." The samples kept at $50^{\circ} \mathrm{F}\left(10.0^{\circ} \mathrm{C}\right)$ rated best in appearance but, as in "shipping green" samples, showed a heavier superficial fungal contamination. These samples rated "acceptable" on the average during the storage tests. All the samples kept at $40^{\circ} \mathrm{F}\left(4.4^{\circ} \mathrm{C}\right)$ developed chilling injury.

The "half-ripe" and "fully ripe" samples behaved the same as the "one- 
fourth-ripe," developing chilling injury at $40^{\circ} \mathrm{F}\left(4.4^{\circ} \mathrm{C}\right)$ and superficial fungal growths at $50^{\circ} \mathrm{F}\left(10.0^{\circ} \mathrm{C}\right)$.

The relative humidities setting at 80 to 70 percent showed a faster dehydration process of the stored fruit. This was revealed by the formation of fissures between the eyes of the fruit. According to the data obtained there were no differences between the settings of 80- and 70-percent relative humidity and the shelf-life of the fruit. The 90-percent relative humidity setting minimized symptoms of humidity loss but increased chances for superficial fungal contamination.

It can be concluded that pineapple fruits of the Red Spanish variety classified as "one-fourth-ripe," are of a better edible quality and have a longer shelf-life than the "shipping green" now being used for export, when stored at $45^{\circ} \mathrm{F}\left(7.2^{\circ} \mathrm{C}\right)$, with a relative humidity ranging from 80 to 90 percent and with proper air circulation.

\section{SUMMARY}

Studies were conducted on the storage behavior of Red Spanish pineapples harvested at four apparently different levels of ripeness. The apparent ripeness classification was based on the yellow-orange area of the fruit. The pineapples were stored and subjected to different conditions of temperature and relative humidity. During storage, the samples were analyzed periodically for chemical constituents and subjected to sensory evaluations. Pineapples classified as "one-fourth-ripe" had a more acceptable rating as far as eating quality when compared with the "shipping green" stage now being harvested by local exporters.

Simulated shipping storage conditions including a temperature of $45^{\circ} \mathrm{F}$ $\left(7.2^{\circ} \mathrm{C}\right)$, a relative humidity ranging from 80 to 90 percent and proper air circulation for 7 days have been found to be acceptable for the "onefourth-ripe" fruit. This fruit can remain in very good salable condition for 9 additional days under supermarket conditions where temperatures of $60^{\circ} \mathrm{F}\left(15.6^{\circ} \mathrm{C}\right)$ and 75 -percent relative humidities prevail.

\section{RESUMEN}

Se llevaron a cabo estudios sobre el comportamiento durante el almacenamiento de la piña Espaniola Roja cosechada en cuatro estados de madurez aparente. La fruta se clasifić respecto a su madurez aparente a base del área de la fruta que mostraba un color amarillo anaranjado. Las frutas se almacenaron bajo diferentes condiciones de temperatura y humedad relativa. Durante el almacenamiento, las frutas se analizaron periódicamente para determinar sus componentes químicos y se evaluaron sensorialmente. La piña clasificada como "un cuarto madura" fue evaluada en cuanto a su calidad como más acept able que la designada "verde para embarque", que es la que se cosecha actualmente para la exportación.

Se determinó que las condiciones controladas de almacenamiento que simulaban las del embarque, o sea una temperatura de $45^{\circ} \mathrm{F}\left(7.2^{\circ} \mathrm{C}\right)$, una humeda relativa que 
variaba entre 80 y 90 por ciento y una circulación de aire adecuada por 7 días eran aceptables para la fruta clasificada como "un cuarto madura". Esta fruta puede mantenerse en condiciones muy buenas de mercadeo por 9 días adicionales bajo las condiciones de almacenamiento que prevalecen en los supermercados, o sea de $60^{\circ}$ F $\left(15.6^{\circ} \mathrm{C}\right)$ y 75 por ciento de humedad relativa.

\section{LITERATURE CITED}

1. Akamine, E. K., Fresh pineapple storage, Hawaii Farm Sci. 12(1): 1-4, 1963.

2. Anuario de Estadísticas Agrícolas de Puerto Rico, 1970-71, The Commonwealth of Puerto Rico, Dep. Agr., p. 42, Sept. 1972.

3. Biale, J. B., The post harvest biochemistry of tropical and subtropical fruits, Adv. Food Res. 10: 293-354, 1960.

4. Dull, G. G., Young, R. E., and Biale, J. B., Respiratory pattern in fruit of pineapple, Anana comosus, detached at different stages of development, Physiologia Pl. 20, 1,059-65, 1967.

5. Gandía, H., and Samuels, G., Cultivo y Elaboración de la Piña en Puerto Rico, Agr. Exp. Sta. Univ. P.R. Bull. 145, October 1945.

6. Henricksen, H. C., Some pineapple problems, Art. 22, Fruit maturity, Porto Rico Agr. Exp. Sta. Agr. Notes 41, May 1928.

7. Kelly, W. P., A study of the composition of Hawaiian pineapples, J. Ind. \& Eng. Chem. 3(6): 403-5, June 1911.

8. Kramer, A., and Ditman, S., Simplified variable taste panel method for detecting flavor changes in vegetables treated with pesticides, Food Technol. 10: 155-9, 1956.

9. Liu, L. J., and Rcdriquez, A., Sexual compatibility, morphology, physiology, pathogenicity and in vitro sensivity to fungicides of Thielaviopsus paradoxa infecting sugarcane and pineapple in Puerto Rico, J. Agr. Univ. P.R. 57(2): 117-28, 1973.

10. Morell, B. M., Roman, F. and Muratti, J., La industria de la piña en Puerto Rico; aspectos agronómicos y económicos; perspectiva, Rev. Agr. P.R. 44: 3-26, 1967.

11. Py, C., La piña tropical, Editorial Blume, Madrid, Spain, 1969.

12. Ramírez, O. D., Gandía, H., and Vélez Fortuño, J., Two new pineapple varieties for Puerto Rico, J. Agr. Univ. P.R. 54(3): 417-28, 1970. 